\title{
Pamenan as an Aesthetic Concept of Creating a Wayang Padang Theatre
}

\author{
Sahrul Nazar ${ }^{1}$ \\ Jurusan Teater, Institut Seni Indonesia Padang Panjang
}

\begin{abstract}
Wayang Padang Theater performance, perceived from the communication perspective, commonly uses a lapau - a traditional coffeestall (pamenan kato)-style dialogue. Meanwhile, Wisran Hadi also makes use of visual aesthetic (pamenan mato). Pamenan is defined as a game, both creatively or philosophically. Dialogue plays an essential role in the performance that can provide a playful sense that sometimes sounds like there is a misscommunication or an altered meaning. This is actually a distinct characteristic of Wisran Hadi in presenting an entertainment through words. Pamenankato is a technique used by Wisran Hadi in creating a work of art that can entertain the society. The society itself is quite appreciative in absorbing the words uttered by the actors on the stage. On he other side, the visual aesthetic or pamenan matois related with thevisual elements shown on the stage. The aesthetic concept of the play can be seen from the use of words or expressions, the flow of the story, the characters, the costumes, the movements, and the organization of stage, music and lighting. These elements are effectively applied by Wisran Hadi in his Wayang Padang performance.
\end{abstract}

Keywords : pamenan; pamenan Kato; pamenan Mato; Wayang Padang; Wisran Hadi

\begin{abstract}
Abstrak
Pamenan sebagai Konsep Estetis Penciptaan Teater Wayang Padang. Pementasan teater Wayang Padang, ditinjau dari segi komunikasi, menggunakan dialog gaya lapau atau warung kopi (pamenan kato). Sementara itu, ditinjau dari segi estetika visual, Wisran Hadi memakai keindahan lihatan (pamenan mato). Pamenan diartikan sebagai permainan, baik permainan secara kreatif maupun permainan secara filosofis. Dialog menjadi hal yang utama dalam pementasan ini. Dialog dalam Wayang Padang seperti bermain-main, kadang-kadang tidak menyambung dan diplesetkan. Hal ini merupakan ciri khas Wisran Hadi dalam menghadirkan hiburan lewat kata-kata. Pamenan kato seperti ini merupakan cara Wisran Hadi dalam membangun karya yang bisa menghibur masyarakat. Masyarakat cukup apresiatif dalam menyimak seluruh kata yang diucapkan oleh aktor di atas pentas. Estetika visual atau pamenan mato berkaitan dengan permainan yang terlihat di panggung pementasan. Estetika konsep penciptaan yang mengarah pada permainan yang terlihat, meliputi unsur kata atau ucapan, cerita, tokoh, kostum, gerak, tata pentas, musik, dan cahaya. Unsur inilah yang dipermainkan oleh Wisran Hadi dalam pementasan teater Wayang Padang.
\end{abstract}

Kata kunci : pamenan; pamenan Kato; pamenan Mato; Wayang Padang; Wisran Hadi

$\overline{1}$ Correspondence: Jurusan Teater, Fakultas Seni Pertunjukan, ISI Padang Panjang. Jln. Bundo Kanduang, Padang Panjang. E-mail: sharief.kirun@gmail.com HP: +628126773609 


\section{Introduction}

Pamenan is defined as a 'game' and can also be defined as 'the beloved' (Dt. Sampono Dirajo, 1972: 270). Pamenan as a game of words in Minangkabau, Sumatra Barat, is derived from the culture that influence the society way of thinking. The word pamenan is frequently used in pepatah, petitih, pasambahan, mamangan adat, etc. It shows that words are essential Minangkabau culture. Pamenan is not just a folk game but also functions as a thinking concept in creating arts. The pamenan patterns in Wisran Hadi's works of art Wayang Padang are taken from the patterns of Minangkabau folk games that adopt the Minangkabau philosophy.

A.A. Navis states that folk games in Minangkabauare open folk arts, they are created by people for people. This is in accordance with the democratic society that supports the philosophy of unity and togetherness among human beings (1984: 263). Hence, the manifestation of arts in Minangkabau can easily experience changes caused by the influence of other cultures. Wisran Hadi's Wayang Padang was performed at Graha Bakti Budaya, Taman Ismail Marzuki, Jakarta, on 14-16 July 2006. The performance portrayed the existence of those changes. Wisran Hadi used the word 'wayang' that is taken from a Javanese term in art. According to Soetarno, wayang originally meant "to cover". For Javanese people, wayang is related to the rotation of the covered or hidden globe. Recently, Wayang is defined as "shadow". However, philosophically, wayang can be also defined as a shadow or reflection of human characteristics (Soetarno, 2005: 152).

Wisran Hadi uses "wayang" since the actors use the technique which is applied in wayang performance, with the use of dolls or scarecrows in the performance. There is the dalang - the director, a story line, and shadow characters. However, in the performance of Wayang Padang, the perception is drawn larger by making the dalang as the person who determines the situations or conditions in the scenes. The word 'Padang', standing for the name of the Sumatra Barat Province Capitol, also means a large savana, an area without tall, woody plants (KBBI, 2008: 1087). It can also explain that 'padang' is a situation which is open and bright. Wisran does not use 'Wayang Minangkabau', but 'Wayang Padang' since the word 'Minangkabau' especially refers to a cultural space, while 'Padang' refers to an administrative zone. In this case, not all Padang people are Minang, while Minang people do not always live in or come from Padang. Wisran Hadi tried to generalize Wayang Padang as an enlightening or brightening performance. The performance also has a complexity of issues such as customary, religious, social, politic and ecomonic problem. It critizes the contemporary issues and this makes the work of arts even more treasured.

\section{Discussion}

Wayang Padang, a performance by Wisran Hadi, carries some religious, cultural, and customary values, as well as economical value that becomes a superior value of the Minangkabau culture. The superior characteristic is well wrapped in the concept of pamenan. The use of pamenan is an effort to consider tradition in enriching modern theater so that contemporer performance has more universal values and stronger Indonesian taste. Through Wayang Padang, Wisran created a performance that Roland Barthes mentions as an intertext work by colaborating various texts within one single text. Respectfully a text which is a web of the quotations from the past history (1981: 39).

The aesthetic concept in Wayang Padang is from the traditional Minangkabau society that refers to an expression that says "nan baik budi, nan endah baso" (the good decorum, the beautiful language). The word 'good' is understood as a combination of ethics and aesthetic. Nothing is considered as good if without benefits and functions, so beauty is meaningless without decorousness. Meanwhile, the word 'endah' (beautiful) is something that is still within the law of ethics. 


\section{Pamenan at Lapau}

Wisran Hadi created words to illustrate Minangkabau human characteristic that enjoys debating-the expression is 'bersilat lidah' or war of the tounges, as depicted in the Wayang Padang text by cutting the words/ syllables in such a way so they will create new meanings. Each word when standing alone will create a new word or it creates a new meaning when combined with another word. The cutting of word or syllable, such as 'anjing — dog—and given a space, and the continued by the word 'menggonggong'barking-will create a different meaning. This word game is frequently played by the Minangkabau society when they gather in a coffee stall which is usually called lapau.

For the new generation, lapau is a place to learn how to mingle and socialize to reach adulthood. At a lapau, they learn about the culture of shame, tolerance, respect so the young people in Minangkabau will choose a proper place to hang out since a stall is designed for various audiences, such as urang sumando, ninik mamak, or young people. At a lapau, they practice to use a proper language style. The language game that they play by debating or symbolizing about their youth. So a lapau is not only designed for young people but also accomodate most members of the society.

A lapau usually looks like an ordinary coffee stall. Inside, we can see a display of snacks or traditional food that normally accompany tea or coffee. In front of the lapau, there is a verandah with long tables and benches to serve the food and drink that people order. Even though people can visit a lapau in their leisure, there are certain times when the lapau will be very packed. The first is in the morning after the morning prayer until 08.00 a.m. The next peak hour is after the afternoon prayer (Solat Ashar) until the time they need to do their evening prayer (Solat Magrib). The last is after the last prayer of the day in the evening (Solat Isya) when people can gather to chat, maota-ota, exchange information, play koa or domino. ${ }^{2}$ Those games can take hours and sometimes even reach the midnight to finish. Therefor, ka lapau (to the stall) is an interactive and democratic culture of the Minangkabau people, which is well known as "lapau democracy".

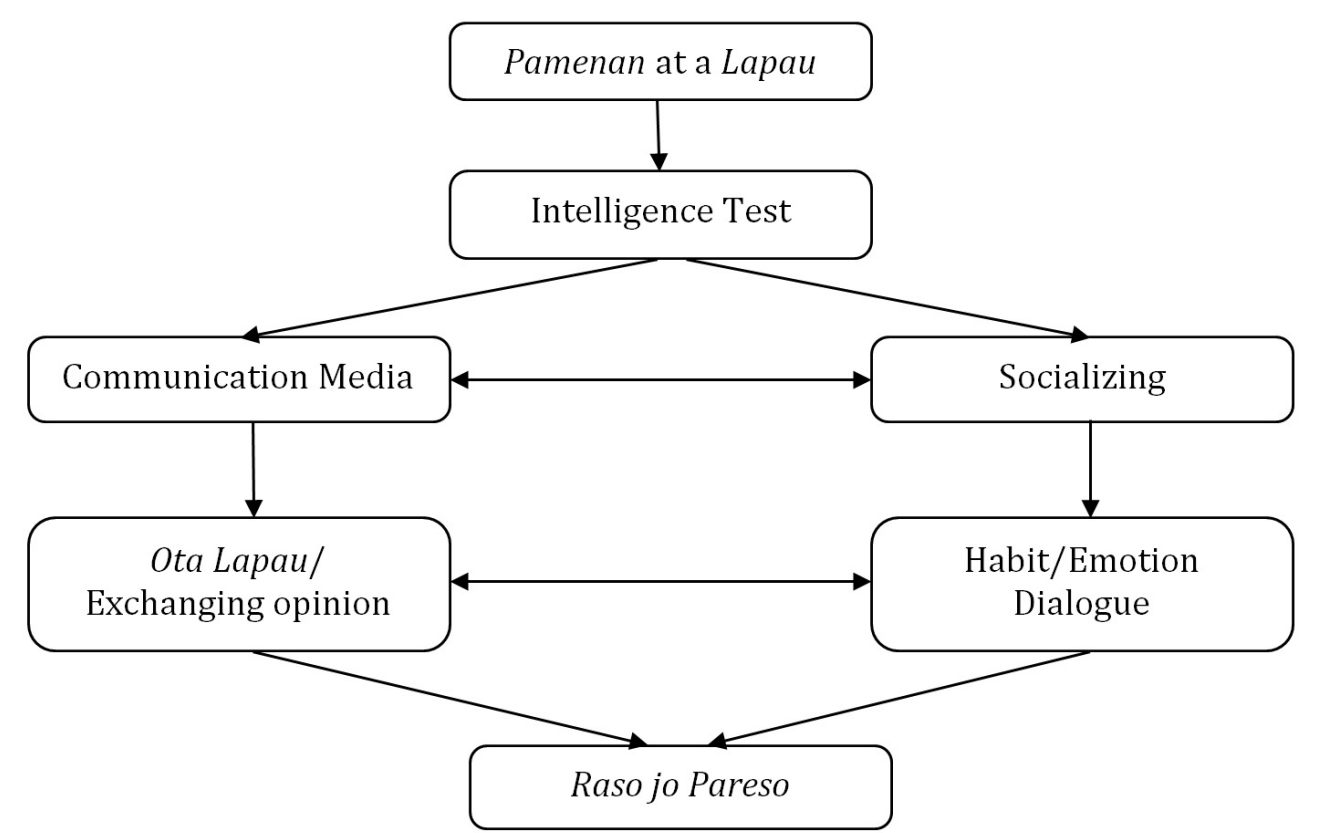

Figure 1. The entity of pamenan at a Lapau that leads to raso jo pareso (emotion and logic/check).

\footnotetext{
2 Maota means talking or discussing a certain theme or topic. Koa is a card game originated from China which is wellknown as ceki game at some other places in Indonesia. Domino is a game without paper card, but it uses a kind of melamine or solid fiber. In some places in Minangkabau it is also called sampilang.
} 
At a lapau, all humans are considered equal. The only thing that shows the difference is how each individual is able to communicate and socialize with others. Each individual is encouraged to keep trying which in Minangkabau is known as 'malawan dunia urang." The value reached in a competition when "melawan dunia orang"-against all odds-is determined from other people's condition and achievements, as told through mamangan and pituah, among others is Baa di urang, baa di awak. ${ }^{4}$ A language, for Minang people, has two functions: as a means of communication for human known as 'kato' meaning word and to show courtesy in life known as 'baso' or attitude. ${ }^{5}$

\section{Pamenan in Word and Dialogue}

Minangkabau habits are adopted by Wisran Hadi into the communication language of contemporary theaters in Sumatra Barat. Sometimes some idioms are played to change the meaning in Wayang Padang performance. From such techniques, a language with new aesthetical values is born in the form of word or a play of language that will create biases. Words in Wisran Hadi's Wayang Padangis delivered in a distictive technique that makes the audience feel enlightened by the chopping of words or the new meaning it creates. Usually, such story is delivered in an illogical way that is far from reality so that the audience can detect that there is something wrong yet they feel entertained.

A village chief uses a strict toned dialoque to tell all farmers to leave their rice fields and there will be no complaints about it. A farmer or the actors do not have anymore opportunity to negotiate since they were already forced to leave their fields. In the story, the strictness shown by the chief is illustrated as a selfish decision that is unbeneficial for the others.

The dialogues in the scenes confirm that Wisran plays with words as practiced in the lapau cultural dialoque. Lapau dialoque style is bordered by the strength of the meaning of the words. The words determine the characters, time, place andoccurences. The same thing applies in randai. A randai without words will not be a randai. It can be seen that the words uttered or sung in the randai can determine the role, place, time and occurences.

Wayang Padang is a theater performance that utters words distinctively so that the audiences might interpret the meanings in different ways. An example of this is in the expression of "anjing, menggonggong, kafilah berlalu"-when a dog barks the traveler keep moving. The word 'anjing'-dog-(dog is a severe swearing word for Indonesian) is cut in such a way so that it sounds like a swearing. The same thing applies to the expression of "kabar burung Penghulu" meaning the news about the chief's bird. When the word 'kabar' is cut, the rest will mean "burung milik Penghulu" meaning the chief's bird (bird can also mean male genital).

\section{Pamenan at the Balai Adat-Custom Hall}

Balai adat is a gathering place for the custom in Minangkabau. This place is used to discuss and debate many current issues, while it also functions to guard the custom values and 'syara'. Minangkabau democracy

\footnotetext{
3 Melawan dunia urang - against all odds-refers to the philosophy that to achieve glory, good reputation, and wealth, people need to continuously compete with each other as stated in the teaching "Mau mulia bertabur urai, mau ternama dirikan kemenangan, mau pintar rajin berguru, mau kaya kuat berusaha." (wanting glory needs efforts, wanting fame needs winning, wanting intelligence needs learning, and wanting wealth needs hard work).

4 Like people like us. If other peope can do it we will be able to do it. If we can do it, others can also do it.

5 "Kato" is spoken words, while "baso" has double meaning. The first is language and the second is human attitudes that lead to courtesy. It is shown from the use of "baso basi" which is a synonym of basa basi-small talk, when they talk about an issue (Interview with Asmali, a prominent person in Minangkabau, dated 21 February, 2013, at Lubuk Aro Pariaman, Sumatra Barat).
} 
takes place here since all chiefs duduak samo randah, tagak samo tinggi-sit as low and stand as tall-where everyone is equal. At the custom hall, pamenan has already reached the comprehensive level. The leadership aspects in nagari (the nation) who are to find the meaning and guard the existence of pamenan in daily life are of village chiefs, religious leaders, and intellectuals which are known as tung ku tigo sajarangan - three burner stoveor tali tigo sapilin-three line thread. These three aspects are didahulukan selangkah dan ditinggikan seranting - one step ahead and one branch taller-meaning leaders who are close to their people.

Penghulu-village chief-is a respected man in a Minangkabau's village. ${ }^{6}$ Penghulu or also known as niniak mamak in the daily life is called "datuak". Each penghulu represents the existing village and a group of penghulus will choose one penghulu chief to lead. Alim ulama are religious leaders in Minangkabau. Their existence is essential to keep the ethics in the society based on Islam religion. The religious leaders are chosen based on their understanding of Islam and they are called "tuanku" - the master. Intellectuals are people with vast knowledge that can find a solution to every problem faced by he society. They usually have good logic, lots of knowledge and are able to update themselves with modern life. The three aspects of leadership ensure that the structure of the nagari will run well including the pamenan of anak nagari-the pamenan of the members of the society.

In general, all aspects of leadership within the nagari in Minangkabau have the same backgrounds: they have lived in a rumah gadang (traditional Minangkabau house), sura (a small mosque), lapau (coffee stall), and rantau (foreign land), and then moving to balai adat (custom hall). Respectively, those chiefs totally understand the life style and attitudes of the younger generations, especially those related to pamenan anak nagari-young people games. With the combination of tungku tigo sajarangan that work hand in hand to develop the life standard and welfare of the society, the people will not lose their way, create unnecessary problems and go into chaos. There is another important leader, Bundo Kanduang-mother (woman) that control the power. Bundo Kanduang is the owner of the state that function as the legislation of the power. Women is positioned as sterile, gracious, free from the self-destructive image.

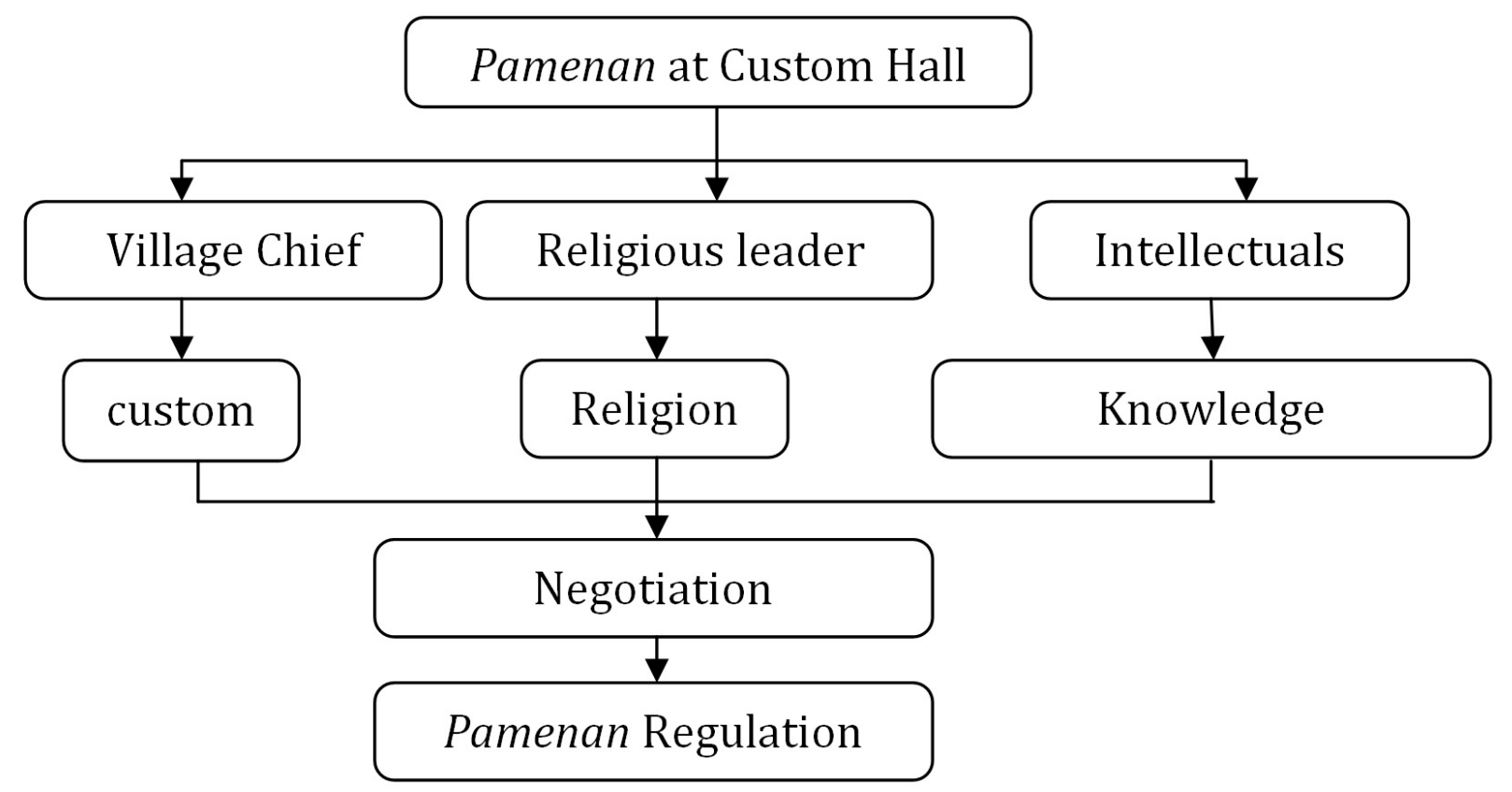

Figure 2. The position of pamenan in the custom hall.

\footnotetext{
$\overline{6}$ One step ahead and one branch atop show how people respect someone important.
} 


\section{Pamenan in Randai}

Traditionally, arts and games in Minangkabau are practiced by young people, therefore the players are called by using 'anak' or child, such as anak randai, anak indang, etc. Meanwhile, the coach is called as "tuo" or the respected elderly. Hence, the age of the Minangkabau traditional art players ranges from 10 to 25 years old, from children to young adults.

Randai uses pamenan patterns by taking idiom of duduak baparintang, tagak bapamenan (sit when there is things to do, stand when there is a game to play), something which is related to the creative concept in Minangkabau society. Randai traditional circle can enlarge and shrink the size of the circle and it happens quite frequently. When the circle shrinks all players clap their hands at the same time in the middle of the circle as if they have an agreement in solving a problem. When the circle enlarges, they start to sit (sit to work immanently) and a character stands in the middle to play trancendentially.

When Galombang randai (the wave of randai) sit down, it starts to work or function immanently in order to set the playground and blend in the game. Sitting does not mean stay passive without any role, a player needs to work by blending in the game and becomes a playground for other players, so that all the actors create a united wave in the game. When an actor plays in the middle of the wave and does an activity as if he does not become something or keeps a distance to something, he plays his own style without transforming into the character he is playing. There is not a special mark that is presented by the visual actor, everything is merely presented in words. When words are uttered, they are respectively considered as the representatives of certain characters.

Working and playing are dualistic harmony that unite in randai game. A trancendent actor and an immanent wave that give a space of comprehension of the relations between human and human and also between human and God. A randai game is a collaboration of the learning process that the Minangkabau People get from rumah gadang (Minangkabau traditinal house), surau (mosque), lapau (coffee stall), and also their understanding of the costums and basic knowledge. The border between the two is the attitude towards the game. The actors'

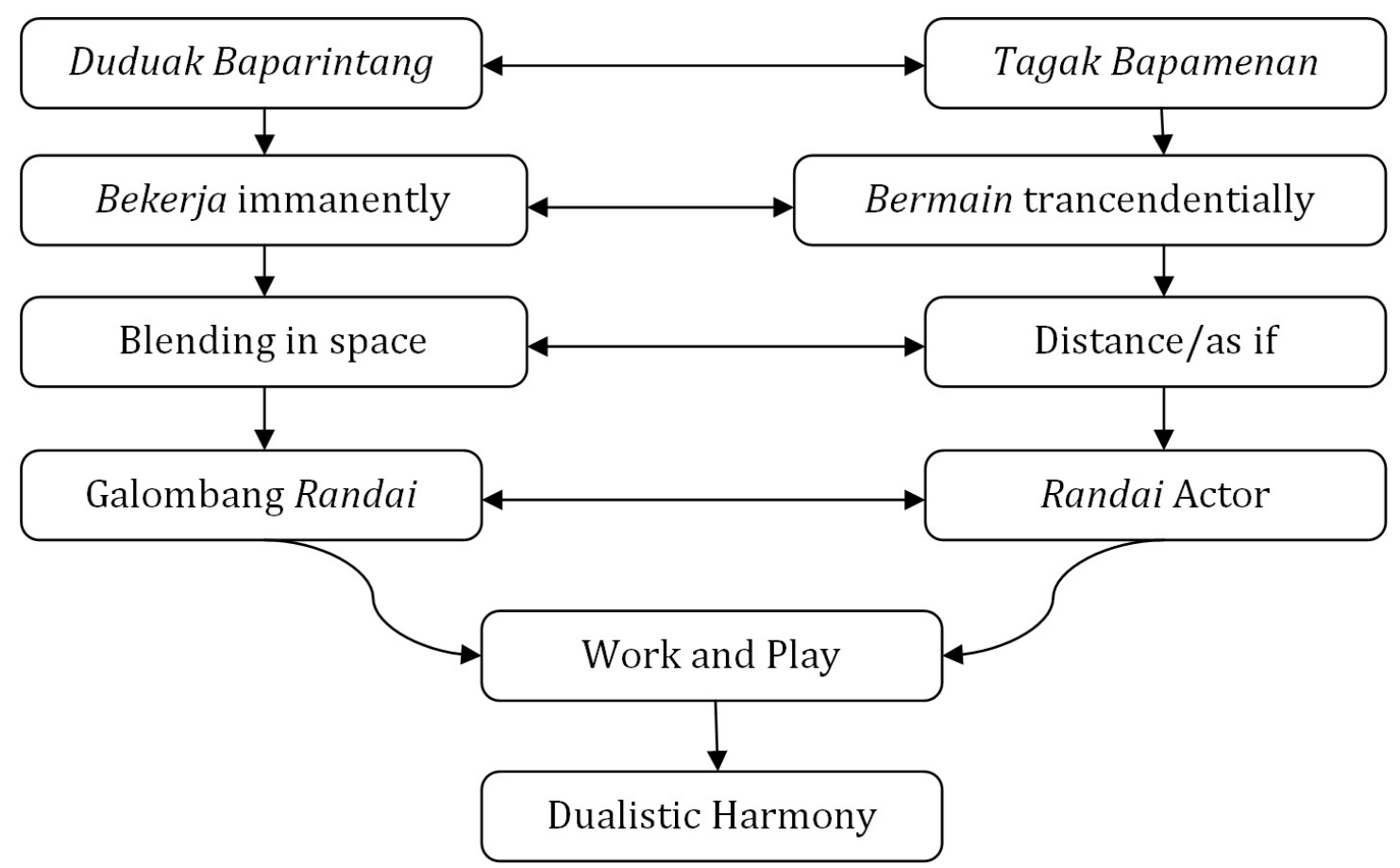

Figure 3. Pamenan in randai applies creative concepts of dualistic harmony: duduak babaparintang and tagak bapamenan. 
behavior is a self interpretation as if he is becoming a different person.

The art concept of the Minangkabau People in general, including randai, is put in three domains within pamenan, they are pamenan kato, pamenan mato, and pemenan raso jo pareso. The three domains cover philosophical, habitual, moral/religious, educational and social values of Minangkabau People. All of those values are united within the visual aesthetic as illustrated in figure 4.

Linguistic aesthetic (pamenan kato) in Minangkabau is related to spoken or oral literature. The presentation of the meaning is given through the language of poetry and lyrical prose. The language of the spoken literature is full of emotional, spiritual, intellectual intelligences. Below is the example of such spoken arts:

\section{Lubuak Basuang tabiangnyo tinggi,} Ikan dijalo tajilapak,
Duduak bamanuang Tolan kini,

Pamenan mato indak tampak.

(Lubuk Basung tebingnya tinggi,

Ikan dijala mati jatuh,

Duduk bermenung Anda kini,

Permainan mata yang tidak kelihatan)

[Basung Gulf with the tall bank

Fishes in the net fall and died

Sitting quietly are you now

Invisibly playing your eyes]

\section{Rumah sikola di Piaman}

Sudah alah baratok balun

Kini balantai batu juo

Buruang lah nampak ka pamenan

Jinak alah katangan balun

Kini di ateh kayu juo

(Rumah sekolah di Piaman

Sudah siap beratap belum

Kini berlantai batu juga

Burung sudah nampak untuk permainan

Jinak sudah ke tangan belum

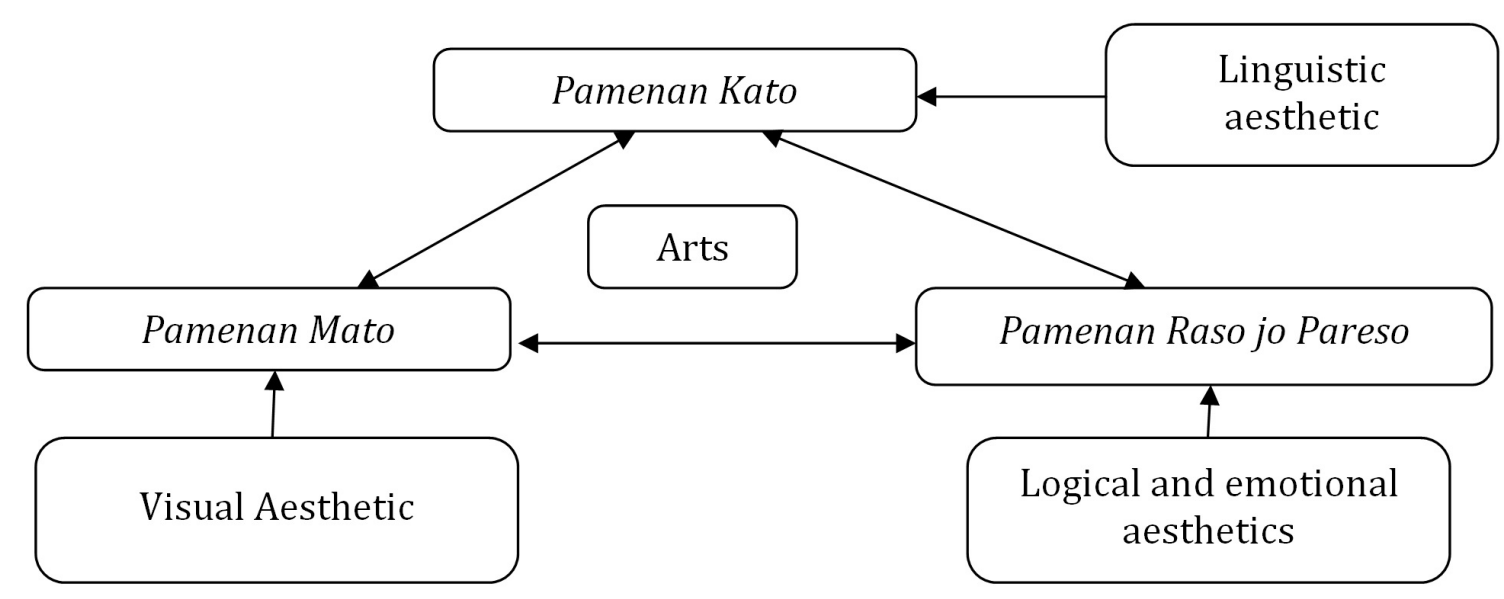

Figure 4. The art concept of the Minangkabau people in general.
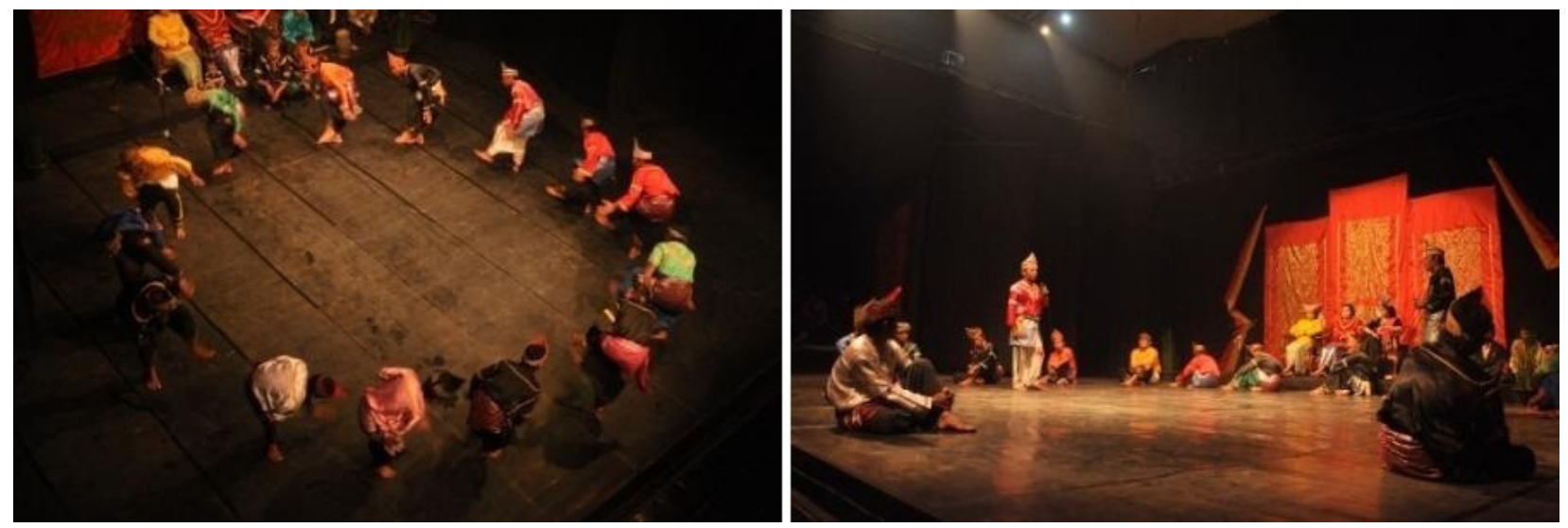

Figure 5. Randai Performance of Intan Korong from Tanah Datar, Sumatra Barat, shows the circle of waves when sitting to work in order to keep the game going, while the actor playing is representing himself.

(Documentation: Department of Theater, ISI Padangpanjang, 2007). 
Kini di atas kayu juga)

[School building at Piaman

All is ready but the roof

Now the floor is from stone

The bird is ready for the game

Already tame but not in hand

Now perching on the wood above]

The poem shows that word pamenan is essential in Minangkabau spoken literature. It shows that pamenan can also become a visual aesthetic (pamenan mato). On the other hand, the emotional and logical aesthetics (pamenanrasa dan periksa) surface when the art takes the emotional, spiritual and intellectual intelligences into consideration.

The movement of galombang randai is derived from the Minangkabau silat-the traditional martial art. Generally, the silat tradition includes distinct kudo-kudo and pitunggua. ${ }^{7}$ Silat does not really have kudokudo, it is better known to have pitunggua. Pitunggua does not show strong position of the feet and legs, but it is more tranquil to take a step. In Minang, there is guyah-guyah garaman which means it is not that strong but not that weak (layah)either. ${ }^{8}$ Meanwhile, kudo-kudo is a very strong stand when the feet and legs do not move at all. Silat shows two terms: "main-play" and "main-mainplayful". "Main-main" or being playful is a movement when there is an attact and dodge by using tangkok ibo (catching with pity) or tangkok lapeh (catching and releasing). On the other side, "main-play" is in a more serious level where tangkok mati (catch and kill) is more dominant.
The terms "main" and "main-main" are the concept of pamenan. In silat there is a sign language that involves movements and sounds. The sign language with hand movements to block shows that the player is not yet ready, therefore the opponents cannot attact. However, if the opponent still attacts in that situation, the one blocking might face a very serious consequence, such as breaking bones. On the other hand, when the hands show that the person is ready to receive the strike, he will show it with his hands and utter sounds like " $a p$ " and "tah". " $A p$ " is from the attacker to ask the opponent whether he is ready. "Tah" says that the opponent is ready to receive the attack.

Randai game has no levels and it depicts the egalitarian Minangkabau society. At social structure level, the egalitarian values are shown in Minangkabau social life. Even though there has been some Hinduism culture, but it does not exist in the Minangkabau society. The story is presented in most randai that start from kaba story in Minangkabau mythology. The mithology ( $k a b a)$ is a reflection that shows not only hope and fears but also the people where the mythology came from (Junus, 1981: 25). Sometimes, some myths reflect the only way to see people of the era since there might not be a written notes of the part of history.

\section{Pamenan in Wayang Padang Theatre}

Wisran Hadi presents the modern performance art in Sumatra Barat by using a traditional concept blended with a modern one. In Wisran Hadi's hands, the pamenan

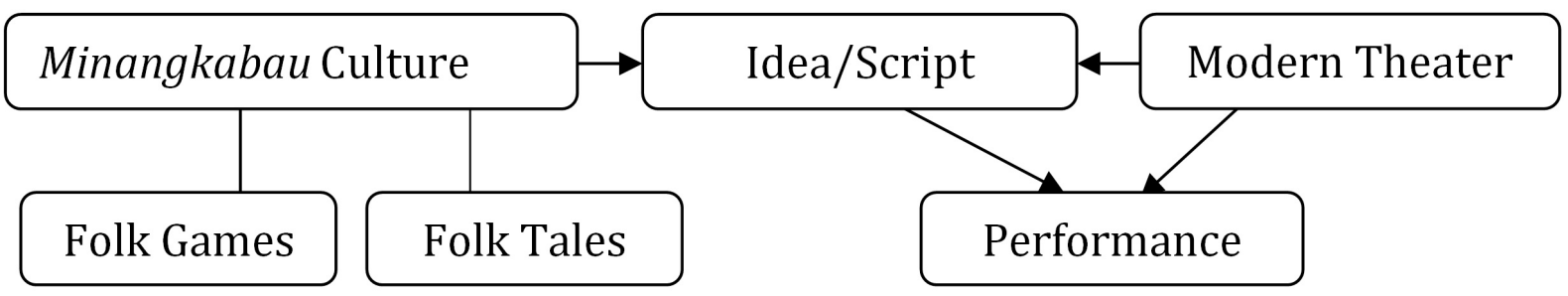

Figure 6. Wisran Hadi's Pattern of work in the Wayang Padang Modern Theater Performance

\footnotetext{
$7 \quad$ Kudo-kudo is a stand with strong legs position. Pituanggua is when the position of the leg is loose, not strong, but a bit relaxed when elasticity is more essential.

8 Longgar-longgar gigi geraham, loose as the molars.
} 
concept is well developed. In the structure of the performance, there is a system combining a variety of pamenans within one performance and there is a guaranteed coherence with the other concepts. Pamenan is traditionally managed to become a modern theater performance. He reconstructs and transforms the values in folktales and history to become drama scripts. The same things also applies to the Minangkabau traditional games, they are restructured and tranformed into a modern theater performance.

Wisran Hadi's Pamenan started when he reinterpreted the Minangkabau culture with its folk tales and games. He puts Minangkabau cultural issues in drama scripts. The scripts function as the guideline in building the modern theater performance. Wisran (2000: 5-6) states that there are some possibilities to prevent oneself from a disadvantageous or unwanted situation. The first is that a Minang person need to believe that the old reference has now become irrelevant to teach the customs to the people in the future. Those old references cannot answer the contemporary problems of the Minang people's, likewise for the future needs. The second is that if those references are kept, there is a need to change the way the people think. Minang intellectuals need to be brave in making a revision, reposition, or reactualization. The third, to answer the future challenges, Minangkabau people need to think and work harder to build a reference framework that accommodates the new customs teaching in order to answer the future challenges. Once in a while, they also need to open their eyes to look at different directions.

Wayang Padang performance is related to pamenan of Minangkabau social and cultural systems that resulted from a bad treatment by the village chiefs (penghulu). The chiefs have sold the family heirloom and that brought up chaotic situations. The changes are experienced by all human in the society both in Minangkabau or in Indonesia, in general. The changes in the society are considered normal, like in the idiom sakali aie gadang, sakali tapian berubah (once big waters come, the river bangs change) since human has unlimited needs. Changes happen after comparing the situation in the past with what people can see now. However, the changes in life are hoped to be positive while in Wayang Padang the changes result in chaotic situations instead of positive development.

In Wayang Padang performance problems of social order cover the relationship system in Minangkabau. The village chief who has a niece (a female character playing as a scare crow) will restore the matrilineal system in Minangkabau-a system which is especially practiced in Minangkabau while other parts of Indonesia practice patrilinial system. The social system also involves the majority of the society that become workers in their own heirloom by becoming farmers and scare crows.

A bird is an important symbol of ruining farming system. A bird does not only steal rice, but also provoke people to change the social and culural systems in the country. The social and cultural changes have a very close relation since a social change will influence in the emergence of a cultural change. Wisran Hadi applies social cultural pamenan in Wayang Padang, by covering some phenomena, they are: 1 ) poverty as a result of selling the family heirloom, 2) a behavioral switch from communal into individual, 3) identity crises, 4) cultural distorsion, and 5) changes in the thinking concept of Minangkabau people. They all occur as globalisation is inevitable.

\section{Patterns of Three and Circle in Wayang Padang}

One of the game patterns employed by Wisran Hadi in Wayang Padang is the use of pattern three. Pattern three is derived from Minangkabau concept on tungkutigo sajarangan and tali tigo sapilin which means there are three structures that support and face each other in order to build the scenes in the performance.

The circle pattern is a traditional Minangkabau game, known as randai. In fact, this pattern is commonly used by primitive 
society as seen Balinese kecak and dances from Papua and Dayak. The initial purpose of the art is a ritual or offering to the invisible powers. By playing in a circle, the middle part is to place the obeisance or the tool to pay respect. In randai the democratic Minangkabau govenance system is portrayed; there is no special treatment given to an actor with higher position. All actors are equal, both in the sitting or standing positions. There is no leveling that puts someone in a feodal position. This also applies to all players and musicians in the performance.

The game in Wayang Padang combines the patterns found in Jalan Lurus dan Anggun Nan Tongga. The patterns on top, middle and bottom are combined by a triangle that focuses on indang game in Minangkabau. As the final work of arts by Wisran Hadi, Wayang
Padang became a complex combination of the two patterns. The pattern of Wayang Padang 1 (WP.1) is formed when building two different areas. The pattern of Wayang Padang 2 (WP.2) is visible in the building of the conflict between a bird and a farmer and is solved by a scarecrow who shakes the bamboo. The same pattern applies to the conflicts between the scarecrow and the village chief, farmer and official, etc. The pattern of Wayang Padang 3 (WP.3) is shown when all players create a setting with the use of the stage properties.

The pattern WP.1 combining top, middle and bottom shows the relations of human with human, human with nature and human with God. While pattern three, like indang tradition, focuses on the relation of tungku tigo sajarangan, between religious leader, village chief, and intellectual in Minangkabau.

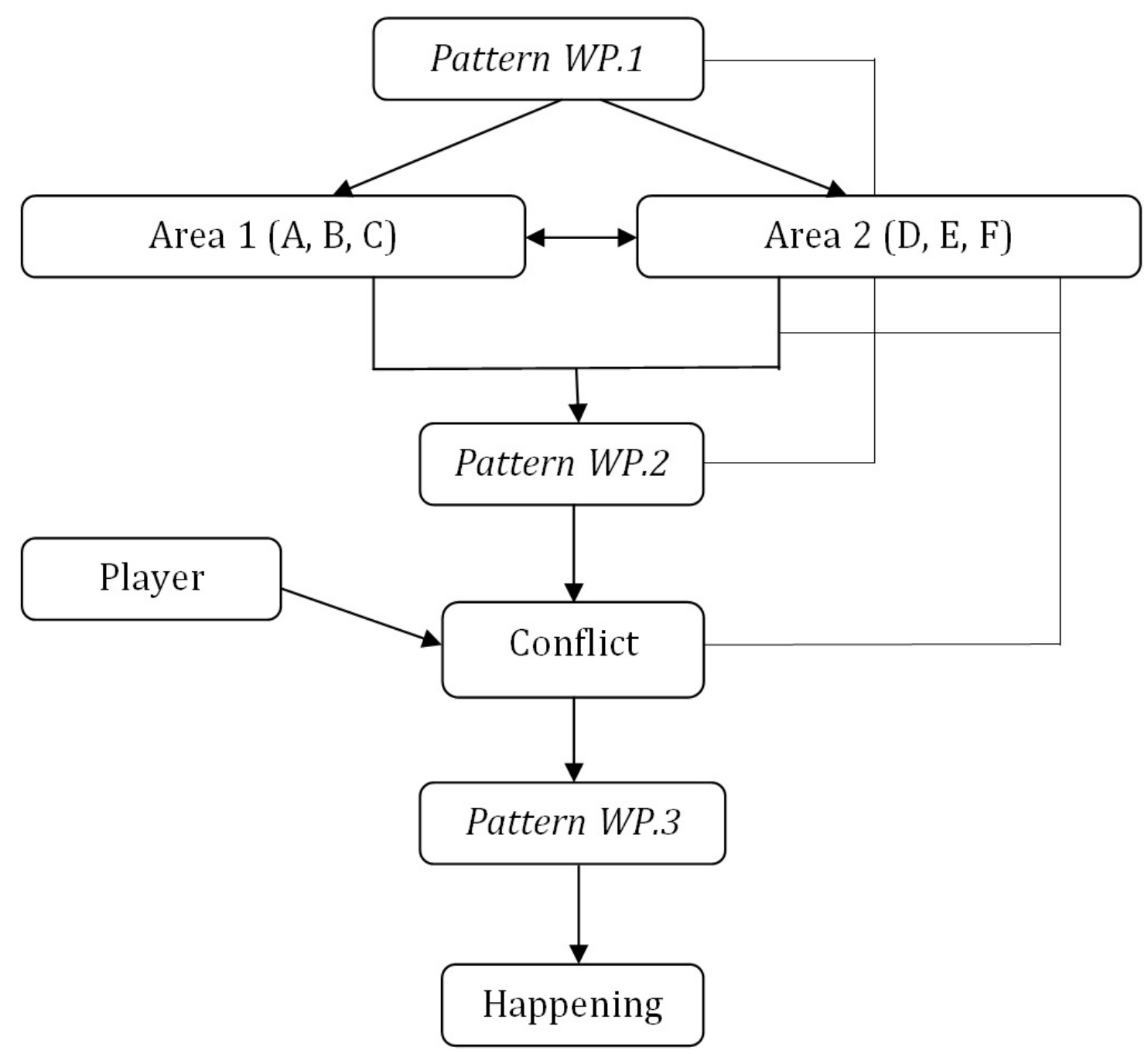

Figure 7. Patterns of three and circle in Wayang Padang. 
The pattern three with $A, B$, and $C$ alphabets shows top, middle and bottom positions. On the other hand, the alphabets D, E, and F illustrate a triangle on the bottom or ground that show the floor. Area A is a place for properties made of bamboo being hang (in Jalan Lurus it is in the form of a bag). When the scarecrow casts out birds, the bamboo shakes and creates loud noises When the bamboo shakes all the birds stealing rice burst out to find a safer place. The hanging bamboo is a symbol of an unbreakable rule in life that also applies to the rice eating birds.

Area A is identical to the relation between human and God. Human depends on God so that their food is not stolen by birds or other pests. God creates everything in the mortal world. God has the will for everything on earth and heaven. Only for God, human is created and only to God human will come back after death. When human hears the name of God, it should be the only one thought staying in his/her mind that is the love towards God/ Allah. All human's deeds which are justified by the love to God, will be easy, beautiful and safe. God is the place for human to complain and human, as the created beings, needs to carry out all God's commands (praying) and avoids God's prohibitions (doing vices or crimes).
Area B is full of standing banana trunks, either at the back, left, or right sides of the stage. The banana trunks are a part of the nature symbolizing the beauty of the human and nature relation that goes well. Human should not ruin nature so that nature will not disturb human. When talking about nature, it covers the rich natural resources or the environment without human activities. Nature has big influences over human. When the nature is ruined by illegal logging there will be negative effects such as flood, landslide, etc. Even worse is when the government and society do not care about the nature and environment by building skycrappers and streets on the green zones, the global warming takes place. This situation forces human to manage the natural resources to avoid ruining the nature. When the nature is disturbed and ruined, as an impact, human's life will also be negatively affected.

Area $C$ is where the actors play. In this area dialogues between roles and humans take place. Humans are created as imperfect so they have positive (good) and negative (bad) traits. Human can help themselves and other creatures to survive in life. Human has unstable personalties that can change easily depending on his/her own interests, for example one can be smart and cunning

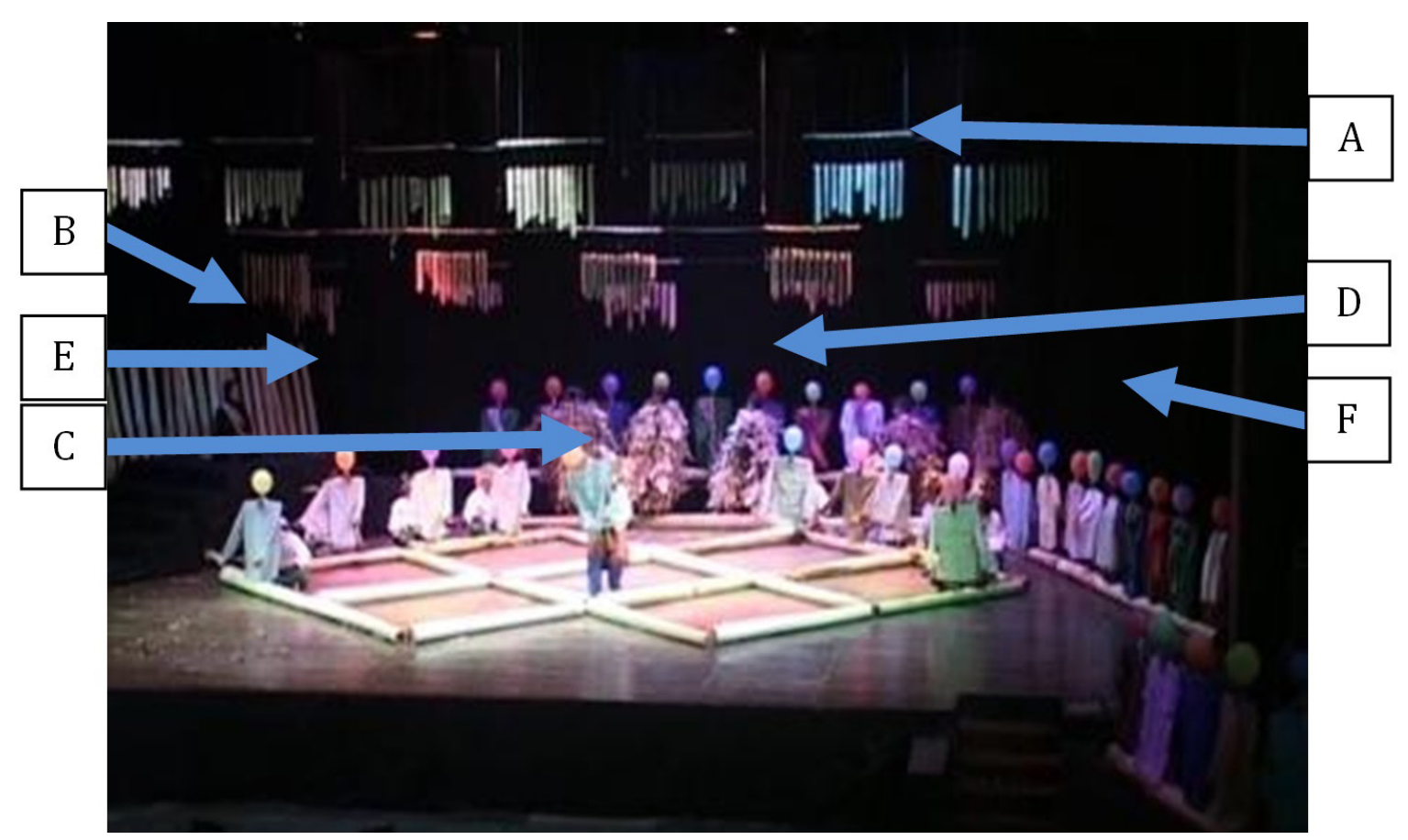

Figure 8. The scene in Wayang Padang with three areas of the game. (Documentation: Bumi Teater, 2006) 
when he is in a favourable situation (like the village chief who wants to sell the land as a family heirloom). The relations between humans in area $\mathrm{C}$ vary, among others are the relations between farmers and the landlord, and scarecrows and the farmer.

The relations between the three areas, $\mathrm{A}$, $\mathrm{B}$, and $\mathrm{C}$ is the core of human life in general. The relation between human, nature and God is very strong. Human always believes that God has created human and nature. That means without God human and nature do not exist. Human culture teaches that humans are supposed to be grateful for what God has given for the survival of human.

The other pattern three is on areas D, E, and $\mathrm{F}$ as an area that shows the relations of the three leadership features in Minangkabau. Area D in Wayang Padang is an area at the back stage where people can see the banana trunks, a collection of Wayang made from baloons, and a group of people that move the wayang. The movements of the wayang is dynamic, always change based on the scenes played. Area $\mathrm{E}$ is where the scarecrows sit while watching the crops and harvest. The place is static, never changes. After finishing a dialogue, the scarecrows return to their initial positions where they can also control the bamboos hanging on the ceiling of the stage. Area F is where the wayangs without the people wait. Those wayangs play as a reserved property to replace the ones being played break down or be ruined. When a player loses his wayang he should take another one from the right side of the stage. This goes on until all the wayangs are ruined.

\section{Pamenan in Wayang Padang Game}

First, pamenan in Wayang Padang game starts with pamenancerita (story pamenan). The story in Wayang Padang is told in pamenan lapau style, the story is straight forwardly developed and sometimes it becomes bias and is easily changed. At the beginning, the story is about the scarecows that watch the scared birds fly away. Suddenly the story changes into the scarecrows which are moved by another hidden power (by the dalang or director).
Later on the story talks about freedom since the scarecrows always feel conquered. It can even touch some issues on local autonomy and others. This story telling style is exactly identical with what happens in a lapau, there is no clear main focus in the story. The story flows with the audiences' agreement without any certain direction, jumping from one theme to another infinitely.

Second, pamanen in the game is directed to the character pamenan in Wayang Padang by Wisran Hadi. The characters' traits are formed by a game that is commonly used in randai; they are in dualistic harmony of duduak baparintang and tagak bapamenan. All the wayangs create a wave when seated, they work to keep the rhytm and when standing up they create a new composition. The actors, the female scarecrow and the village chief, act like in randai: when making a dialogue, they enter the wave circle and when quiet they only sit in the left level of the audience or outside the stage. Galombang (wave) in Wayang Padang is not only in the form of a circle like in randai, but it can also proceed into a line, triangle, or others.

The wayangs have the characteristics of Minangkabau people in general, such as galie (cunning), paota (witty), and friendly ( $d i$ mana bumi dipijak di sana langit dijunjungstanding on the ground and lifting the sky). The pamenan characteristics of the village chief reflect the Minangkabau negative or bad village chief. The village chief who is pressured by the modernization, does not act in accordance with the local culture and beliefs. They sell the heirlooms for their own interests (galie or cunning). The Minangkabau village chief is part of the Minangkabau leadership, together with the religious leader and intellectals (tungku tigo sajarangan). The absence of the other two components in the leadership indicates the alteration of the cultural system. The chief has become the haegemony that dictates all the Minangkabau issues. The inadequate leadership has brought chaos in the society. The uprooted religion from the Minangkabau society brings a big influence that changes the order and habit of 
the people because "adatnya bersendi syarak, syaraknya bersendi kitabullah" and "syarak mangato (to say) soadat mamakai (to do)". This principles, according to Wisran Hadi, are already scarcely applied. Consequently, the chief becomes a dictator to the people.

Third, word or spoken pamenan in Wayang Padang is a pamenan of pasambahan dialogue habit, a dialogue with fast thinking process that determines the course of the dialogue. The uttered word is like an improvisation and then it is gone just like that. It is made purposefully so that the words will only pass in a while to tickle the audiences' conscience.

Fourth, costume pamenan, is how Wisran Hadi puts efforts in designing and managing costumes in Wayang Padang so they look interesting yet are considered polite. The actors who play the wayang wear long sleeved white moslem shirts with pants of various colors (black, green, brown and blue). On their waists, there are folded sarongs and crownshaped old banana leaves are tied on their heads. The folded sarong symbolizes the tie of truth while, at the same time, ties the pants in order to keep them from getting loose.

Costume pamenan in Wayang Padang shows the habit of Minangkabau people who are Moslem. In Minangkabau culture, clothes show one's identity, i.e. the village chief wears black clothes with no decoration and no pockets. When clothes no longer show the identity there will be biases in the rules of conduct of the chief in carrying out his role in the custom rituals.

The wayangs played also wear costumes that show their identities. The wayangs wear old long-sleeved shirts with no pants and the heads are made of colorful balloons. The clothes are commonly used by farmers to cover scarecrows in the rice field. The use of baloons for the heads is Wisran Hadi method to allude human whose head is totally empty.

The costume for the bird flock is called simuntu, made of dried banana leaves weaved to cover the body. The birds also wear sunglasses and head dresses. The simuntu costume shows how the traditional people attract attention in a certain occasion such as independence day, cultural or religious celebrations.

The costumes of the female scarecrows are of baju basiba or baju kurung, a special Minangkabau blouse, with a scarf which ends are intertwined at the waist and completed with a veil. Under the blouse there is a loose long skirt that reaches the ankles. The costumes symbolize the Minangkabau people that respect their traditional custom and Islam as their life guidance.

Fifth, movement pamenan on Wayang Padang stage is more of group movement, especially for the groups of farmers, scarecrows, and birds. The birds mostly move while dancing. The movement of the wayangs tend to use randai style, moving together then sitting, moving again and sitting again by stabbing the wayangs into the banana trunks to make them stand on the floor. The movement is set by moving when the wayang will start a dialogue, all wayangs will do the same. When randai using silat (traditional martial art) it moves in a circle, in Wayang Padang the moves are more dynamic based on the prosenium stage space, they are not always in a circle but can be in a line, gathering in the middle of the stage, spreading out, etc.

Sixth, stage and property pamenan in Wayang Padang mostly make use of what is available in nature. Banana trunk, bamboo, and dried banana leaves are all commonly used to enliven the stage. It shows the good relations between human and nature. Human need to interact well with animals, plants and other environmental aspects since human cannot live alone without the help of the natural resources around them.

The bamboo properties are hang on the ceiling of the stage. Almost all parts of the stage is full bamboo which are well-arranged. The front part of the stage has taller bamboos that create an illustration of an opened mouth with sharp teeth which are ready to bite. When the wayangs are played and stabbed on the banana trunk to stand on the floor of the stage, it seems that the teeth are grinding the wayangs.

Another property used by Wisran Hadi in Wayang Padang is the wayangs themselves. 
The wayangs are made to resemble living creatures which are operated by human actors. It shows that Wisran Hadi is also influenced by doll theater. Doll theater performs the story line by using dolls as the characters which are operated by the a dalang or director. The dolls can be in the forms of leather or doll puppets in Java. However, in Wayang Padang, each doll has its own dalang or director that can move to any directions in accordance with the will of the dalangs.

Seventh, musical pamenan in Wayang Padang is composed of internal and external music. Internal music is the sounds made by the players on the stage such as the sound of the moving bamboo, the sound of the dried banana leaves made by the birds, or baloon blast blown by the players. On the other hand, external music is played by the musician outside the stage in the forms of vocal, guitar, gendang or sampelong.

\section{Conclussion}

In Wayang Padang performance by Wisran Hadi, the pamenan concept in Minangkabau culture lies on three spheres, namely surau (mosque), lapau (coffee stall), and balai adat (custom hall). Surau is where they learn pamenan, lapau is a place to practice pamenan, and balai adat is where pamenan given the meanings.

Randai as the basic of the Wayang Padang creation has its own pamenan concept. Randai uses pamenan pattern by taking the idiom of duduak baparintang, tagak bapamenan (sitting when there is something to do, standing when there is a game to play). Galombang randai or randai wave is sitting when working or functioning immanently, and standing, moving in a circle trancendently to create a playground for and unite with the game.

Pamenan in Wayang Padang is related, in general, with the Minangkabau culture pamenan and, especially, Indonesian pamenan. Pamenan in Wayang Padang is also related to Islam. The performance of Wayang Padang by Wisran Hadi is related with Adat Basandi Syarak, Syarak Basandi Kitabullah (the relation with God), saciok bak ayam, sandanciang bak basi (the relation with other humans), and alam takambang jadi guru (the relation with nature). The three aspects can be seen in the performance textures, such as the costumes to cover aurat, the use of properties taken from nature, and God's anger to human bad deeds.

Pamenan physically tends to use the pattern three and circle pattern. The pattern three is derived from the terms of tungkutigo sajarangan and tali tigo sapilin, which means three structures that face and support each other to build the scenes in the performance. The pattern three is illustrated in the division of the game groups: the wayang, female scarecrows and village chief. The area of the game also uses the pattern three: top, middle and bottom (vertically), and right, middle and left (horizontally). The circle pattern in Wayang Padang is shown in the movement of the players that broaden, srink or ruin the space of the game.

Pamenans which are related to the scenes in the Wayang Padang among others include story pamenan, character pamenan, costume pamenan, dialogue pamenan, stage property pamenan, movement pamenan, lighting pamenan, and music or sound pamenan. The story telling uses lapau style, the characters are of the Minangkabau people, the costumes are also those of Minangkabau people and so is the nature as the background.

\section{References}

Barthes, Roland. 1981. "Theory of the Text", dalam Robert Young, Unitying the Text, A Post Structuralist Reader, London and New York: Routledge.

Dirajo, Dt. Sampono. 1972. Mustika Adat Minangkabau. Bukittinggi: Angkasa.

Navis, A. A. 1984. Alam Terkembang Jadi Guru Adat dan Kebudayaan Minangkabau. Jakarta: Grafiti Press.

Pusat Bahasa Departemen Pendidikan Nasional. 2008. Kamus Besar Bahasa Indonesia. Jakarta: Balai Pustaka.

Soetarno. 2005. Pertunjukan Wayang dan Makna Simbolisme. Surakarta: Pascasarjana ISI. 